ACTA UNIVERSITATIS NICOLAI COPER NICI DOI: http://dx.doi.org/10.12775/AUNC_ECON.2013.003 EKONOMIA XLV nr 1 (2014) 41-58

Pierwsza wersja złożona 21 listopada 2013

\author{
Edyta Laszkiewicz*
}

\title{
WPŁYW KONKURENCYJNOŚCI NA POZIOM WYNAGRODZEŃ W KRAJACH EUROPY. ANALIZA Z WYKORZYSTANIEM MODELU TRENDU POWIERZCHNIOWEGO**
}

$\mathrm{Z}$ a r y s tre ści. Celem artykułu jest określenie wpływu konkurencyjności gospodarki na poziom przeciętnych wynagrodzeń godzinowych w wybranych krajach Europy. Dodatkowo podjęto próbę identyfikacji przestrzennej tendencji rozwojowej zjawiska przy wykorzystaniu modelu trendu powierzchniowego, bazującego na współrzędnych geograficznych stolic krajów. W szerszym kontekście zawarte w pracy rozważania mają uwydatnić kwestie związane $\mathrm{z}$ wprowadzeniem komponentu przestrzennego w analizach zjawisk ekonomicznych.

S ło w a k l u c z o w e: wynagrodzenia, konkurencyjność, model trendu powierzchniowego.

K 1 a s yfik a c j J E L: J31, C21.

\section{WSTĘP}

Konkurencyjność jest jedna z najszerzej rozumianych kategorii, charakteryzujących jednostki ekonomiczne. Utożsamiana jest zarówno z wielością walorów ekonomicznych, jakimi dysponuje jednostka (np. region, kraj), jak i sprawnością systemu społeczno-gospodarczego (Kłosiński, 2004, s. 11). Konkurencyjność wyraża pozycję i potencjał rozwojowy jednostki, co czyni

\footnotetext{
* Adres do korespondencji: Edyta Łaszkiewicz, Uniwersytet Łódzki, Katedra Ekonometrii Przestrzennej, ul. Rewolucji 1905 r. 37, 90-214 Łódź, e-mail: elaszkiewicz@uni.lodz.pl.

** Praca zrealizowana w ramach projektu „Doktoranci - Regionalna Inwestycja w Młodych naukowców społeczno-humanistycznych - Akronim D-RIM SH” współfinansowanego przez Unię Europejską ze środków Europejskiego Funduszu Społecznego w ramach Programu Operacyjnego Kapitał Ludzki, Poddziałanie 8.2.1.
}

(C) 2014 Uniwersytet Mikołaja Kopernika. All rights reserved. http://www.aunc.ekonomia.umk.pl 
ją predestynowaną do roli czynnika wyjaśniającego zmiany innych kategorii ekonomicznych, m.in. poziomu wynagrodzeń. Mimo prac teoretycznych i empirycznych, dowodzących oddziaływania konkurencyjności na wysokość płac, nieeksponowanym aspektem pozostaje osadzenie tej relacji w przestrzeni geograficznej i próba scharakteryzowania jej z punktu widzenia zachodzących w tej przestrzeni zmian.

Celem opracowania jest zbadanie relacji między poziomem konkurencyjności gospodarki a przeciętnym poziomem płac godzinowych. Dodatkowo w pracy podjęto próbę określenia charakteru przestrzennych zmian wysokości wynagrodzeń. W opracowaniu postawiono hipotezę dotyczącą pozytywnego wpływu konkurencyjności na poziom wynagrodzeń oraz hipotezę mówiącą o tym, że poziom płac w krajach Europy cechuje niejednorodność $\mathrm{w}$ postaci trendu przestrzennego. Weryfikację postawionych hipotez umożliwiło zastosowanie modeli trendu powierzchniowego. W badaniu wykorzystano dane dotyczące płac dla 32 krajów Europy za 2010 r.

\section{PODSTAWY TEORETYCZNE}

W rozdziale tym dokonano krótkiej charakterystyki powiązań między konkurencyjnością a rynkiem pracy oraz przedstawiono tę relację z punktu widzenia analiz przestrzennych.

\subsection{KONKURENCYJNOŚĆ A RYNEK PRACY}

W teoretycznych rozważaniach dotyczących konkurencyjności gospodarki wiąże się ją najczęściej ze ścieżką rozwoju jednostki i szeroko pojmowanym dobrobytem społeczeństwa (Jagiełło, 2008, s. 31). Z punktu widzenia analizy relacji między poziomem konkurencyjności a wysokością płac, związek ten wydaje się ogrywać zasadniczą rolę. Konkurencyjność gospodarki charakteryzowana jest $\mathrm{w}$ tym przypadku odpowiednimi miernikami, które odzwierciedlają sytuację gospodarczą (Kwiatkowski, Kucharski, 2011). W rezultacie konkurencyjność rozpatrywana jest przez pryzmat wzrostu produktywności jednostki (np. kraju), zaś gospodarka postrzegana jest jako bardziej konkurencyjna w sytuacji, gdy posiada zdolności do podnoszenia produktywności (w porównaniu z innymi gospodarkami).

$\mathrm{Z}$ perspektywy teorii wzrostu gospodarczego nakreślić można powiązania między konkurencyjnością a rynkiem pracy. Jak wskazują Kwiatkowski i Kucharski (2011), relacje między obiema kategoriami są: 1) dwustronne, 2) zależne od przyjętego horyzontu czasowego oddziaływania. Dwustronność relacji oznacza w tym przypadku możliwość oddziaływania konkurencyjności na poziom płac, a płac na konkurencyjność gospodarki. Uzależnie- 
nie od rozpatrywanego horyzontu rozumiane jest natomiast jako zmiana mechanizmu wpływu konkurencyjności na podstawowe kategorie charakteryzujące rynek pracy w perspektywie krótko- i długookresowej. W rezultacie efekty krótkookresowe oddziaływania konkurencyjności na rynek pracy mogą być negatywne (np. redukcja popytu na pracę i wzrost bezrobocia - będące wynikiem wzrostu wydajności pracy), natomiast efekty długookresowe wiążą się z pozytywnymi zmianami. W szczególności możliwa jest redukcja jednostkowych kosztów pracy, zaś wzrost produkcji i wydajności pracy mogą przełożyć się na wzrost poziomu wynagrodzeń.

\subsection{MODEL TRENDU POWIERZCHNIOWEGO}

Jak podkreśla Lewandowska-Gwarda (2013), usytuowanie w określonej przestrzeni geograficznej ma duży wpływ na kształtowanie się zjawisk ekonomicznych. W analizie relacji między konkurencyjnością a wynagrodzeniami (lub szerzej: kategoriami odzwierciedlającymi sytuację na rynku pracy) wartości obu zmiennych przypisać można punktom w czasie i/lub przestrzeni geograficznej. Ukierunkowanie na wymiar przestrzenny analizy wiąże się m.in. $\mathrm{z}$ nurtem $\mathrm{w}$ badaniach określanym jako nowa ekonomia geograficzna.

Z punktu widzenia analizy przestrzennej zjawiska (w tym ekonomicznego) istotną rolę odgrywa podział procesu na dwie składowe: trend - wyrażający systematyczne zmiany zjawiska w określonym kierunku (kierunkach), oraz składnik resztowy - reprezentujący trudne do wyjaśnienia zmiany procesu. Jedną z najbardziej podstawowych metod matematyczno-statystycznych, służących analizie pierwszej $\mathrm{z}$ wymienionych składowych procesu przestrzennego, jest model przestrzennej tendencji rozwojowej. Pozwala on zidentyfikować powierzchnię trendu przestrzennego, a co za tym idzie wspomaga wnioskowanie dotyczące charakteru przestrzennego rozkładu zjawiska. Mimo niewątpliwych korzyści płynących z zastosowania metody trendu powierzchniowego, jak wskazują Chojnicki i Czyż (1975), tempo jej upowszechniania $\mathrm{w}$ geografii ekonomicznej było znacznie wolniejsze niż w przypadku m.in. geologii.

Brak przestrzennej jednorodności $\mathrm{w}$ odniesieniu do płac i poziomu konkurencyjności, rozpatrywać można (w najprostszym ujęciu) przede wszystkim przez pryzmat podziału na Europę Wschodnią i Zachodnią oraz Północną i Południową. Chociaż przestrzenne dysproporcje między poszczególnymi częściami Europy są wyraźne, różnicowanie może przybierać formę trendu przestrzennego lub może być rozpatrywane jako przestrzenna heterogeniczność. W przypadku trendu przestrzennego zmiany odzwierciadla funkcja ciągła, zaś podział przestrzeni geograficznej na jednorodne gru- 
py może być utrudniony. Dla porównania, w przypadku heterogeniczności charakter przestrzennej niejednorodności odzwierciedla funkcja nieciągła, co prowadzi do możliwości podziału krajów na jednorodne grupy.

\section{METODA BADANIA}

W celu empirycznej weryfikacji sformułowanych w punkcie 1 hipotez teoretycznych wykorzystano modele trendu powierzchniowego uwzględniające relację przyczynowo-skutkową między poziomem wynagrodzeń a konkurencyjnością gospodarki. Niniejszy punkt podzielono na dwie części najpierw omówiono narzędzie badania, później zaś scharakteryzowano wykorzystane $\mathrm{w}$ analizie dane statystyczne.

\subsection{MODEL TRENDU POWIERZCHNIOWEGO}

Zjawisko ekonomiczne - w przestrzeni geograficznej - traktować można jako dwuwymiarowe pole losowe, którego wymiary odzwierciedlają długość i szerokość geograficzną (Pietrzak, 2010). Uwzględnienie dodatkowo związków przyczynowo-skutkowych prowadzi do uzyskania modelu przyjmującego postać ogólną:

$$
y_{i}=f\left(u_{i}, z_{i}, \varepsilon_{i}\right),
$$

gdzie:

$y_{i}$ - wektor $N \times 1$ regresanta,

$u_{i}=\left(x_{i}, y_{i}\right)$ - współrzędne długości i szerokości geograficznej,

$z_{i}$ - macierz $N \times K$ regresorów,

$\varepsilon_{i}$ - wektor $N \times 1$ składnika losowego.

$\mathrm{Z}$ punktu widzenia analizy struktury przestrzennej zjawiska $u_{i}$ traktować można jako jeden $\mathrm{z}$ dwóch, obok $\varepsilon_{i}$, komponentów charakteryzujących zjawisko $\mathrm{w}$ przestrzeni geograficznej (lub bardziej ogólnie $\mathrm{w}$ zdefiniowanej przez badacza przestrzeni). Jak wskazuje Pietrzak (2010), $u_{i}$ odzwierciedla systematyczną niejednorodność zjawiska, wyrażającą się w średniej procesu przestrzennego, którą określić można mianem trendu przestrzennego. Dla porównania, analiza przestrzenna składnika losowego pozwala uchwycić zmienność zjawiska o stałej w przestrzeni (jednorodnej) średniej, co może prowadzić do identyfikacji zależności przestrzennych.

W zależności od charakteru zmian zjawiska w przestrzeni, można rozpatrywać liniowy trend przestrzenny lub przestrzenną tendencję rozwojową o charakterze nieliniowym - wyrażoną np. za pomocą wielomianu drugiego 
stopnia (lub wyższych). W niniejszej pracy estymacji poddano model trendu liniowego (2) i modyfikację trendu centralnego (3) w postaci:

$$
\begin{aligned}
& y_{i}=\alpha_{0}+\alpha_{1} u_{x, i}+\alpha_{2} u_{y, i}+\alpha_{3} z_{i}+\varepsilon_{i}, \\
& y_{i}=\alpha_{0}+\alpha_{1} u_{x, i}+\alpha_{2} u_{x, i}{ }^{2}+\alpha_{3} u_{y, i}+\alpha_{4} u_{y, i}{ }^{2}+\alpha_{5}\left(u_{x, i} u_{y, i}\right)+\alpha_{6} z_{i}+\varepsilon_{i},
\end{aligned}
$$

gdzie:

$y_{i}$ - logarytm naturalny przeciętnego poziomu wynagrodzeń na godzinę pracy w kraju $i$ w 2010 r., wyrażony w parytecie siły nabywczej (PPS, EU28=1),

$z_{i}-$ logarytm naturalny wartości indeksu konkurencyjności GCI w kraju $i$, opóźniony o $t$ okresów,

$u_{x, i}, u_{y, i}$ - współrzędne długości i szerokości geograficznej centroidu kraju $i$,

$\alpha$-parametry modelu.

$\mathrm{W}$ sytuacji gdy jednostkami przestrzennymi są poligony (np. regiony, kraje), zastosowanie modelu trendu powierzchniowego wiąże się z koniecznością wyznaczenia - dla każdego obiektu - punktu reprezentującego jego położenie w przestrzeni geograficznej. W tradycyjnym ujęciu jako centroid przyjmuje się geometryczny środek obiektu. Jedną z wad takiego sposobu definiowania centroidu jest możliwość uzyskania współrzędnych punktu znajdującego się poza poligonem. Sytuacja taka ma miejsce w przypadku jednostek przestrzennych będących figurami wklęsłymi (Liu, 2000, s. 165). Mając na względzie powyższe, jak również biorąc pod uwagę, że analizowane jest zjawisko ekonomiczne, w pracy jako ,środek” kraju przyjęto stolicę, utożsamiając ją z miejscem koncentracji działalności gospodarczej.

\subsection{DANE STATYSTYCZNE}

W badaniu wykorzystano dane dla 32 krajów europejskich za lata 2005-2010, pochodzące z Eurostatu (dane dotyczące poziomu płac) oraz Światowego Forum Ekonomicznego (globalny indeks konkurencyjności). Wysokość płac zdefiniowano jako średni poziom wynagrodzeń brutto (wyrażonych w PPS) za godzinę pracy (w przedsiębiorstwach zatrudniających minimum 10 osób) oszacowanych na podstawie wyników Badań Struktury Wynagrodzeń (SES - structure of earnings survey) ${ }^{1}$. Uzyskane dane zaprezentowano na rysunku 1.

${ }^{1}$ Badanie realizowane jest co cztery lata, przy czym ostatnie miało miejsce w $2010 \mathrm{r}$. 


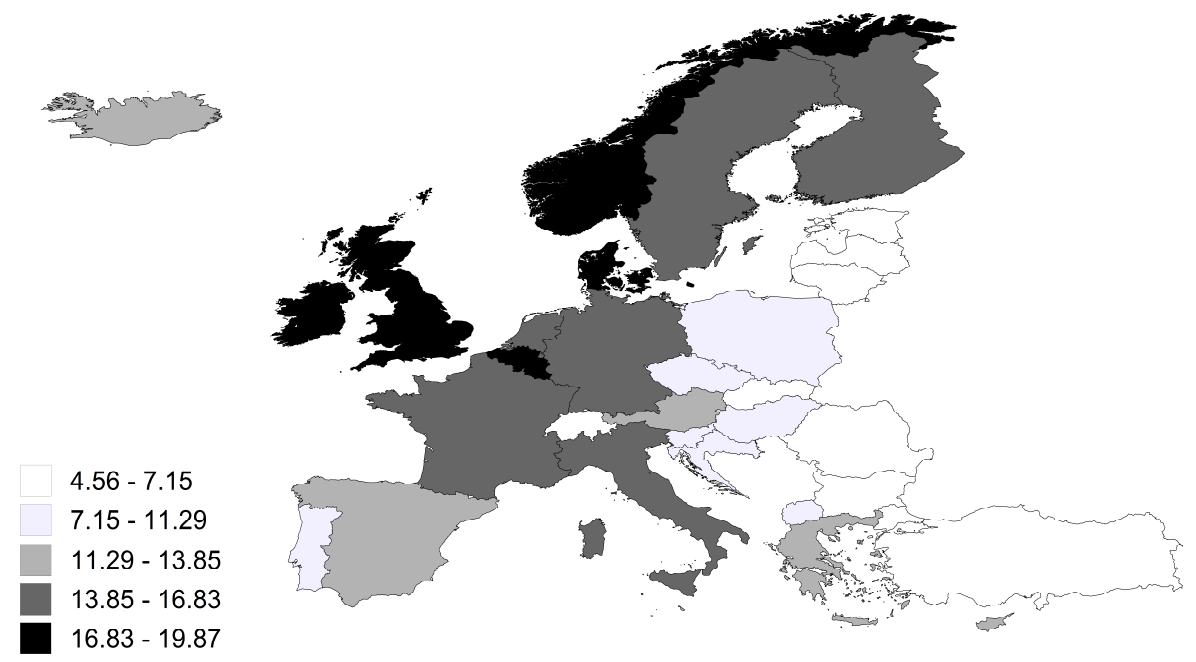

Rysunek 1. Średnie wynagrodzenie brutto za godzinę pracy w 2010 r. (w PPS)

Źródło: opracowanie własne na podstawie danych Eurostatu.

W rozpatrywanej grupie państw najniższą wartością płac cechowały się kraje zlokalizowane na Półwyspie Bałkańskim (Turcja, Rumunia, Bułgaria, Macedonia) oraz tzw. kraje bałtyckie (Estonia, Litwa i Łotwa). Dla porównania, najwyższy poziom wynagrodzeń za godzinę pracy - w 2010 r. - odnotowano w takich krajach jak: Norwegia (19,16 PPS/godz.), Dania $(19,72)$, Irlandia $(19,87)$ czy Luksemburg $(18,29)$.

Wstępna analiza danych pozwala wnioskować o znaczących dysproporcjach w poziomie wynagrodzeń w krajach Europy, przy czym najsilniejsze różnice widoczne są między krajami Europy Zachodniej i Środkowo-Wschodniej (wraz z Półwyspem Bałkańskim). W porównaniu z danymi za 2006 r., skala dysproporcji uległa zwiększeniu, przy czym w obu okresach trzy pierwsze i trzy ostatnie kraje - pod względem poziomu płac - były takie same.

Jako miarę konkurencyjności gospodarki przyjęto wartość indeksu konkurencyjności (GCI - global competitiveness index). GCI jest miernikiem agregatowym, skonstruowanym na podstawie ok. 100 wskaźników, z czego część pochodzi z badań ankietowych (Schwab, Sala-i-Martin, Greenhill, 2009). Wskaźnik GCI obejmuje zmienne charakteryzujące 12 filarów: otoczenie instytucjonalne, infrastrukturę, stabilność makroekonomiczną, ochronę zdrowia i edukację wczesnoszkolną, naukę i szkolnictwo wyższe, efektywność rynku, wielkość rynku dóbr i usług, rynek pracy, innowacyjność, poziom rozwoju technologicznego, otoczenie biznesowe, rynek finansowy. 
Im wyższa wartość wskaźnika GCI, tym bardziej konkurencyjna jest gospodarka danego kraju.
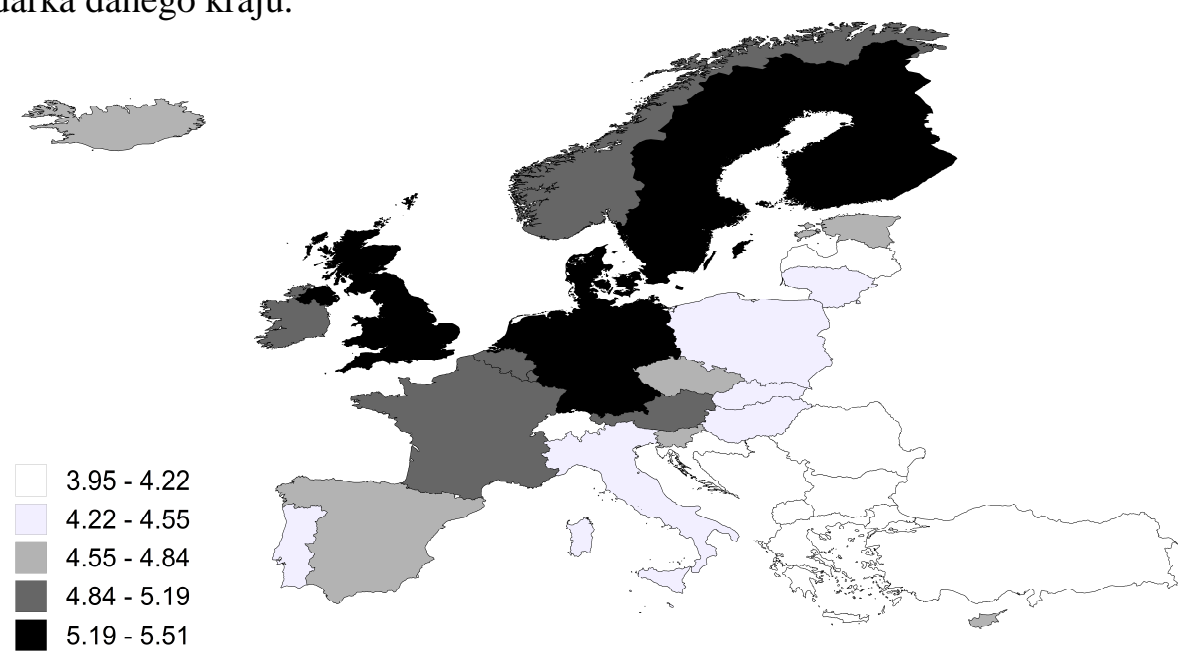

Rysunek 2. Wartość globalnego indeksu konkurencyjności (GCI) za lata 2009-2010

Źródło: opracowanie własne na podstawie danych Światowego Forum Gospodarczego.

Analiza wartości indeksu konkurencyjności GCI pozwala zauważyć, że w krajach najbardziej konkurencyjnych wynagrodzenie również jest wysokie. Analogicznie kraje, których pozycja konkurencyjna jest niewielka, to przede wszystkim te, które zaklasyfikowane zostały do grona krajów o najniższym poziomie wynagrodzeń godzinowych. Na przestrzeni lat 2005-2010 pozycja konkurencyjna czterech krajów o najniższej wartości GCI pozostała niemal taka sama. W całym rozważanym okresie najmniej konkurencyjnym krajem była Macedonia. Wśród innych wskazać można: Bułgarię, Rumunię, Turcję, Chorwację i Grecję. Dla porównania, najbardziej konkurencyjnymi gospodarkami w tym okresie były: Szwecja, Finlandia, Dania, Niemcy, przy czym ich pozycja w całym okresie analizy była stabilna.

\section{WYNIKI ANALIZY EMPIRYCZNEJ}

Całość analizy podzielono na trzy etapy, znajdujące odzwierciedlenie w strukturze części 3 artykułu. W pierwszej kolejności oszacowano model regresji liniowej (pkt 3.1), na podstawie którego zweryfikowano hipotezy dotyczące wpływu konkurencyjności na poziom płac oraz charakteru tej relacji. W dalszej kolejności zaprezentowano wyniki estymacji modeli trendu powierzchniowego (pkt 3.2). Wykorzystano je do weryfikacji hipotezy mó- 
wiącej o istnieniu systematycznej niejednorodności wysokości płac w krajach Europy. Rozdział zamyka omówienie wniosków z badań (pkt 3.3).

\subsection{WYNIKI ESTYMACJI MODELU REGRESJI LINIOWEJ}

We wszystkich modelach (por. tabela 1) zmienna aproksymująca poziom konkurencyjności gospodarki okazała się istotna statystycznie, potwierdzając wpływ konkurencyjności na poziom wynagrodzeń godzinowych. Im bardziej konkurencyjna była gospodarka danego kraju w poprzednich latach, tym wyższy poziom płac godzinowych odnotowała w 2010 r. Uzyskane wyniki wskazują ponadto, że kolejne opóźnienia indeksu GCI determinują w coraz słabszym stopniu zmiany poziomu płac, o czym świadczy stopniowy spadek wartości oszacowania parametru $\beta$. Istotny statystycznie wpływ konkurencyjności na poziom wynagrodzeń zaobserwowano dla wszystkich rozważanych opóźnień, tj. od roku do pięciu lat. Jednakże dla opóźnienia rzędu pięciu lat siła oddziaływania na wysokość płac znacząco zmalała w porównaniu $\mathrm{z}$ oszacowaniami parametru $\beta \mathrm{w}$ pozostałych modelach. Systematycznej redukcji uległ również współczynnik determinacji, potwierdzając tym samym stopniowy spadek zdolności dyskryminacyjnych indeksu GCI.

W porównaniu z wynikami uzyskanymi przez Kwiatkowskiego i $\mathrm{Ku}-$ charskiego (2011) dla powiatów w Polsce, zauważyć można, że w przypadku analizy na poziomie krajów siła wpływu konkurencyjności na zmiany wynagrodzeń jest wyższa. Wspomniani autorzy uzyskali, że jednoprocentowy wzrost poziomu konkurencyjności powiatu $\mathrm{w}$ okresie $t-1$ spowoduje wzrost poziomu płac o $0,77 \%$ (przy założeniu ceteris paribus). Dla porównania, oszacowania modelu dla próby 32 krajów Europy wskazują, że wzrost indeksu GCI o $1 \%$ w roku $t$-1 prowadzi do wzrostu wynagrodzeń godzinowych (wyrażonych w PPS) o 3,17\%. Analogiczne różnice widoczne są również dla wyższych rzędów opóźnień zmiennej niezależnej.

Różnice w oszacowaniach wynikać mogą po części innego horyzontu czasowego przyjętego w badaniu oraz specyfikacji zmiennych, w szczególności indeksu konkurencyjności, który w niniejszej pracy uwzględnia znacznie szerszy zakres wskaźników. Dodatkowo różnice w uzyskanych oszacowaniach wynikać mogą $\mathrm{z}$ przyjętego szczebla agregacji przestrzennej danych.

Tempo redukcji oddziaływania konkurencyjności na poziom płac, mierzone spadkiem wartości oszacowania parametru $\beta$ dla kolejnych opóźnień indeksu GCI, jest jednak zbliżone do wyników uzyskanych przez Kwiatkowskiego i Kucharskiego (2011). Dla opóźnienia $t$-4 wartość parametru $\beta$ stanowi $85 \%$ wartości parametru oszacowanego dla opóźnienia $t$-1, podczas gdy u Kwiatkowskiego i Kucharskiego (2011) było to $86 \%$. 
Tabela 1. Wyniki estymacji wpływu konkurencyjności gospodarki na poziom wynagrodzeń (KMNK)

\begin{tabular}{|c|c|c|c|c|c|c|}
\hline Parametr & $\alpha$ & $\operatorname{se}(\alpha)$ & $\mathrm{R}_{\text {skor. }}{ }^{2}$ & $\begin{array}{c}\text { Test Shapiro- } \\
\text {-Wilka } \\
\end{array}$ & $\begin{array}{l}\text { Test Breuscha- } \\
\text {-Pagana }\end{array}$ & $\begin{array}{c}\text { Test istotności } \\
\text { Morana I } \\
\end{array}$ \\
\hline $\begin{array}{c}\text { const. } \\
\ln \left(\mathrm{GCl}_{2009}\right)\end{array}$ & $\begin{array}{c}-2,48^{\star *} \\
3,17^{* *}\end{array}$ & $\begin{array}{l}0,67 \\
0,42\end{array}$ & $62 \%$ & 0,42 & 0,14 & $0,01^{* *}$ \\
\hline $\begin{array}{c}\text { const. } \\
\ln \left(\mathrm{GCl}_{2008}\right)\end{array}$ & $\begin{array}{l}-2,30^{\star *} \\
3,03^{* *}\end{array}$ & $\begin{array}{l}0,63 \\
0,39 \\
\end{array}$ & $60 \%$ & 0,51 & 0,06 & $0,01^{* *}$ \\
\hline $\begin{array}{c}\text { const. } \\
\ln \left(\mathrm{GCl}_{2007}\right)\end{array}$ & $\begin{array}{r}-1,87^{\star \star} \\
2,76^{\star *}\end{array}$ & $\begin{array}{l}0,64 \\
0,40\end{array}$ & $54 \%$ & 0,49 & $0,03^{*}$ & $0,00^{* *}$ \\
\hline $\begin{array}{c}\text { const. } \\
\ln \left(\mathrm{GCl}_{2006}\right)\end{array}$ & $\begin{array}{c}-1,85^{\star \star} \\
2,69\end{array}$ & $\begin{array}{l}0,58 \\
0,36 \\
\end{array}$ & $56 \%$ & 0,69 & 0,09 & $0,00^{* *}$ \\
\hline $\begin{array}{c}\text { const. } \\
\ln \left(\mathrm{GCl}_{2005}\right)\end{array}$ & $\begin{array}{l}-0,85 \\
2,12^{* *}\end{array}$ & $\begin{array}{l}0,56 \\
0,36 \\
\end{array}$ & $49 \%$ & 0,09 & 0,39 & $0,00^{* *}$ \\
\hline
\end{tabular}

$* * \mathrm{p}<0,01 ; * \mathrm{p}<0,05$. Dla testu Shapiro-Wilka, Breuscha-Pagana i testu istotności globalnej autokorelacji przestrzennej Morana I podano wartość $p$-value. Wskaźnik Morana I oszacowany dla macierzy dwóch najbliższych sąsiadów.

Źródło: obliczenia własne.

Analiza własności składników losowych oszacowanych modeli pozwala wnioskować o normalności rozkładu reszt, jak również ich homoskedastyczności. Istotna statystycznie wartość współczynnika globalnej autokorelacji przestrzennej ${ }^{2}$ Morana $I$ (Suchecki, 2010) każdorazowo wskazuje jednak na przestrzenne skorelowanie reszt. Fakt ten daje podstawy do wnioskowania o istnieniu powiązań przestrzennych, bez możliwości uściślenia sposobu oddziaływania.

Etap budowy modeli trendu powierzchniowego poprzedzono estymacją modeli przestrzennych (SAR, m-SAR, SEM, SDM i SAC) dla macierzy wag sąsiedztwa rzędu od jednego do trzech najbliższych krajów. Uzyskane oszacowania parametrów dla efektów przestrzennych (prezentacja szczegółowych wyników została pominięta w niniejszej racy) okazały się nieistotne statystycznie. W estymowanych modelach przestrzennych reszty były skorelowane przestrzennie, przy zachowaniu normalności ich rozkładu i homoskedastyczności. Co więcej, estymacja wpływu szerokości i długości geograficznej na reszty modeli potwierdziła statystyczną istotność lokalizacji, prowadząc do wyjaśnienia ok. 30\% zmienności składnika losowego. Mając na uwadze powyższe, dokonano estymacji modeli trendu powierzchniowego.

${ }^{2}$ W obliczaniach wykorzystano macierz dwóch najbliższych sąsiadów. 


\subsection{WYNIKI ESTYMACJI MODELI TRENDU POWIERZCHNIOWEGO}

W pierwszej kolejności, dla każdego punktu w czasie, estymacji poddano modele liniowego trendu przestrzennego (tabela 2). Uzyskane wyniki wskazują, że w przypadku indeksu konkurencyjności przestrzenna tendencja rozwojowa pozwala wyjaśnić 34-54\% zmienności zjawiska. Z wyjątkiem 2005 r., zauważyć można systematyczny spadek wartości współczynnika determinacji w kolejnych modelach, co świadczyć może o tym, że w ostatnich latach coraz mniej wyraźny był określony kierunek przestrzennych zmian indeksu konkurencyjności.

Tabela 2. Wyniki estymacji modeli liniowego trendu powierzchniowego dla indeksu GCI i płac godzinowych wraz z wizualizacją

\begin{tabular}{|c|c|c|c|c|c|c|c|}
\hline \multirow{2}{*}{$\begin{array}{l}\text { Zmienna } \\
\text { zależna }\end{array}$} & \multirow[b]{2}{*}{ Parametr } & \multicolumn{6}{|c|}{ Indeks GCI (1) } \\
\hline & & $\alpha$ & $\operatorname{se}(\alpha)$ & $\mathrm{R}_{\text {skor. }}{ }^{2}$ & $\begin{array}{c}\text { Test Shapiro- } \\
\text {-Wilka }\end{array}$ & $\begin{array}{l}\text { Test Breuscha- } \\
\text {-Pagana }\end{array}$ & $\begin{array}{c}\text { Test istotności } \\
\text { Morana I }\end{array}$ \\
\hline \multirow{3}{*}{$\ln \left(\mathrm{GCl}_{2009}\right)$} & const. & $1,22^{\star *}$ & 0,10 & & & & \\
\hline & $\operatorname{coor} X$ & $-0,00$ & 0,00 & $34 \%$ & 0,20 & $0,05^{*}$ & $0,01^{* *}$ \\
\hline & $\operatorname{coor} Y$ & $0,01^{* *}$ & 0,00 & & & & \\
\hline \multirow{3}{*}{$\ln \left(\mathrm{GCl}_{2008}\right)$} & const. & $1,20^{\star *}$ & 0,09 & & & & \\
\hline & $\operatorname{coor} X$ & $-0,00^{*}$ & 0,00 & $43 \%$ & 0,14 & 0,11 & $0,00^{* *}$ \\
\hline & coor Y & $0,01^{* *}$ & 0,00 & & & & \\
\hline \multirow{3}{*}{$\ln \left(\mathrm{GCl}_{2007}\right)$} & const. & $1,14^{\star \star}$ & 0,08 & & & & \\
\hline & $\operatorname{coor} X$ & $-0,00^{*}$ & 0,00 & $50 \%$ & 0,58 & 0,07 & $0,00^{* *}$ \\
\hline & coor Y & $0,01^{* *}$ & 0,00 & & & & \\
\hline \multirow{3}{*}{$\ln \left(\mathrm{GCl}_{2006}\right)$} & const. & $1,15^{\star \star}$ & 0,10 & & & & \\
\hline & $\operatorname{coor} X$ & $-0,00^{*}$ & 0,00 & $54 \%$ & 0,13 & 0,16 & $0,00^{* *}$ \\
\hline & $\operatorname{coor} Y$ & $0,01^{* *}$ & 0,00 & & & & \\
\hline \multirow{3}{*}{$\ln \left(\mathrm{GCl}_{2005}\right)$} & const. & $1,12^{\star \star}$ & 0,15 & & & & \\
\hline & $\operatorname{coor} X$ & $-0,00^{*}$ & 0,00 & $42 \%$ & 0,98 & 0,25 & $0,03^{*}$ \\
\hline & coor Y & $0,01^{* *}$ & 0,00 & & & & \\
\hline & & \multicolumn{6}{|c|}{ Płace godzinowe (1) } \\
\hline \multirow{3}{*}{ In(Wage2010) } & const. & $2,60^{\star *}$ & 0,10 & & & & \\
\hline & $\operatorname{coor} X$ & $-0,02^{\star *}$ & 0,01 & $20 \%$ & 0,10 & 0,16 & $0,00^{\star *}$ \\
\hline & $\operatorname{coor} \mathrm{Y}$ & - & - & & & & \\
\hline
\end{tabular}

** $\mathrm{p}<0,01 ; * \mathrm{p}<0,05$. Dla testu Shapiro-Wilka, Breuscha-Pagana i testu istotności globalnej autokorelacji przestrzennej Morana I podano wartość $p$-value. Wskaźnik Morana I oszacowany dla macierzy dwóch najbliższych sąsiadów.

Źródło: obliczenia własne.

W każdym z oszacowań szerokość geograficzna okazała się istotna statystycznie. Wartość parametru jest stabilna w czasie, co oznacza, iż w latach 2005-2009 wzrost szerokości geograficznej o jeden stopień powodował wzrost wartości indeksu GCI średnio o 0,01\%. Dodatkowo, w latach 2005-2008 wartości indeksu konkurencyjności malały pod wpływem wzrostu 
długości geograficznej, przy czym siła oddziaływania tej zmiennej na wartość indeksu GCI była niższa niż w przypadku szerokości geograficznej i nie przekraczała $0,01 \%$ dla każdej zmiany o jeden stopień.

Wyniki estymacji modelu trendu powierzchniowego dla płac godzinowych potwierdzają statystyczną istotność długości geograficznej, przy czym jej wpływ jest silniejszy niż w przypadku indeksu GCI. Wzrost długości geograficznej o jeden stopień prowadził do zmiany poziomu płac godzinowych średnio o 0,02\% w 2010 r. Wyrażona w ten sposób przestrzenna tendencja rozwojowa wyjaśniła $20 \%$ zmienności wysokości wynagrodzeń godzinowych w Europie.

Zgodnie z powyższym, najwyższy poziom płac godzinowych widoczny był w krajach zlokalizowanych na północy, a najniższy w Europie Południowej (por. rysunek 3). Dla porównania, najbardziej konkurencyjne gospodarki zlokalizowane były w Europie Północno-Zachodniej. Im dalej na południe i wschód, tym mniejsza była wartość indeksu GCI, a co za tym idzie mniej konkurencyjna gospodarka.
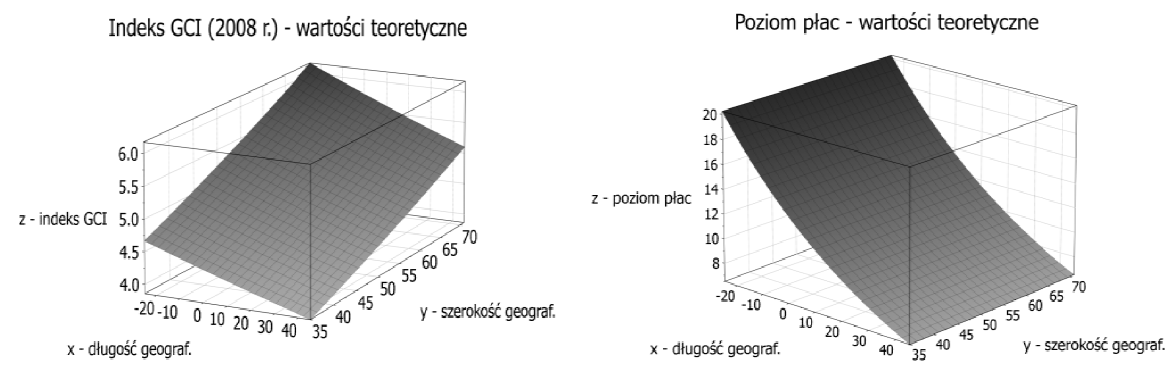

Rysunek 3. Liniowy trend powierzchniowy dla indeksu GCI (2008) i wynagrodzeń Źródło: opracowanie własne na podstawie tabeli 2.

W dalszej kolejności rozszerzono model trendu powierzchniowego dla płac godzinowych, uwzględniając wpływ konkurencyjności (tabela 3, model 1). Dla każdego punktu w czasie oszacowane modele cechowały się znacznie lepszym dopasowaniem wartości teoretycznych do danych rzeczywistych niż poprzednie (tabela 1 i 2). Co więcej, uzyskane w toku kolejnych estymacji reszty cechowały się normalnością rozkładu, homoskedastycznością oraz brakiem autokorelacji przestrzennej. Wyjątek stanowił model, w którym indeks GCI opóźniono aż o pięć lat. Oznacza to, że istotna statys- 
Tabela 3. Wyniki estymacji modeli liniowego trendu powierzchniowego z zależnością między płacami a konkurencyjnością gospodarki

\begin{tabular}{|c|c|c|c|c|c|c|}
\hline \multirow{2}{*}{ Parametr } & \multicolumn{6}{|c|}{ Model 1} \\
\hline & $\alpha$ & $\operatorname{se}(\alpha)$ & $\mathrm{R}_{\text {skor. }}{ }^{2}$ & (1) & (2) & (3) \\
\hline const. & $-2,14^{* *}$ & 0,61 & \multirow{4}{*}{$70 \%$} & \multirow{4}{*}{0,54} & \multirow{4}{*}{0,37} & \multirow{4}{*}{0,24} \\
\hline $\ln \left(\mathrm{GCl}_{2009}\right)$ & $3,61^{* *}$ & 0,36 & & & & \\
\hline coor $X$ & $-0,01^{*}$ & 0,00 & & & & \\
\hline coor Y & $-0,02^{* *}$ & 0,01 & & & & \\
\hline const. & $-2,23^{\star \star}$ & 0,60 & \multirow{4}{*}{$69 \%$} & \multirow{4}{*}{0,22} & \multirow{4}{*}{0,37} & \multirow{4}{*}{0,29} \\
\hline $\ln \left(\mathrm{GCl}_{2008}\right)$ & $3,75^{\star \star}$ & 0,38 & & & & \\
\hline $\operatorname{coor} X$ & $-0,01$ & 0,00 & & & & \\
\hline $\operatorname{coor} Y$ & $-0,02^{* *}$ & 0,00 & & & & \\
\hline const. & $-1,94^{\star *}$ & 0,63 & \multirow{4}{*}{$66 \%$} & \multirow{4}{*}{0,07} & \multirow{4}{*}{0,50} & \multirow{4}{*}{0,22} \\
\hline $\ln \left(\mathrm{GCl}_{2007}\right)$ & $3,68^{* *}$ & 0,46 & & & & \\
\hline $\operatorname{coor} X$ & $-0,01$ & 0,00 & & & & \\
\hline coor $Y$ & $-0,03^{* *}$ & 0,01 & & & & \\
\hline const. & $-2,17^{\star \star}$ & 0,62 & \multirow{4}{*}{$71 \%$} & \multirow{4}{*}{0,09} & \multirow{4}{*}{0,40} & \multirow{4}{*}{0,31} \\
\hline $\ln \left(\mathrm{GCl}_{2006}\right)$ & $3,86^{\star \star}$ & 0,46 & & & & \\
\hline coor X & $-0,00$ & 0,00 & & & & \\
\hline $\operatorname{coor} Y$ & $-0,03^{* *}$ & 0,01 & & & & \\
\hline const. & $-0,39$ & 0,64 & \multirow{4}{*}{$52 \%$} & \multirow{4}{*}{0,17} & \multirow{4}{*}{0,10} & \multirow{4}{*}{$0,03^{*}$} \\
\hline $\ln \left(\mathrm{GCl}_{2005}\right)$ & $2,37^{\star *}$ & 0,47 & & & & \\
\hline $\operatorname{coor} X$ & $-0,01$ & 0,01 & & & & \\
\hline $\operatorname{coor} Y$ & $-0,02$ & 0,01 & & & & \\
\hline & \multicolumn{6}{|c|}{ Model 2} \\
\hline const. & $2,60^{* *}$ & 0,06 & \multirow{3}{*}{$70 \%$} & \multirow{3}{*}{0,70} & \multirow{3}{*}{0,20} & \multirow{3}{*}{0,17} \\
\hline $\ln \left(\hat{G} C_{2009}\right)$ & $3,61^{* *}$ & 0,50 & & & & \\
\hline coor X & $-0,02^{* *}$ & 0,00 & & & & \\
\hline const. & $2,60^{\star *}$ & 0,06 & & & & \\
\hline $\ln \left(\hat{G} C l_{2008}\right)$ & $3,75^{\star \star}$ & 0,54 & $69 \%$ & 0,80 & 0,14 & 0,22 \\
\hline $\operatorname{coor} X$ & $-0,02^{* *}$ & 0,00 & & & & \\
\hline const. & $2,60^{\star *}$ & 0,07 & & & & \\
\hline $\ln \left(\hat{G} C l_{2007}\right)$ & $3,69^{* *}$ & 0,57 & $66 \%$ & 0,57 & 0,32 & 0,18 \\
\hline coor X & $-0,02^{* *}$ & 0,00 & & & & \\
\hline const. & $2,60^{\star \star}$ & 0,06 & & & & \\
\hline $\ln \left(\hat{G} C_{2006}\right)$ & $3,86^{* *}$ & 0,54 & $70 \%$ & 0,61 & 0,21 & 0,29 \\
\hline coor X & $-0,02^{* *}$ & 0,00 & & & & \\
\hline const. & $2,60^{* *}$ & 0,08 & & & & \\
\hline $\ln \left(\hat{G} C_{2005}\right)$ & $2,37^{\star *}$ & 0,51 & $52 \%$ & 0,12 & 0,07 & $0,03^{*}$ \\
\hline $\operatorname{coor} X$ & $-0,02^{* *}$ & 0,01 & & & & \\
\hline
\end{tabular}

** $\mathrm{p}<0,01 ; * \mathrm{p}<0,05$. Dla testów Shapiro-Wilka (1), Breuscha-Pagana (2) i testu istotności globalnej autokorelacji przestrzennej Morana I (3) podano wartość $p$-value. Wskaźnik Morana $I$ oszacowany dla macierzy dwóch najbliższych sąsiadów.

Źródło: obliczenia własne. 
tycznie wartość wskaźnika Morana I mogła wynikać z niewłaściwej specyfikacji modelu, w którym pominięto przestrzenną tendencję rozwojową, a nie $\mathrm{z}$ istnienia interakcji przestrzennych.

Mimo pożądanych własności składnika losowego oszacowane wartości parametrów trendu przestrzennego są niestabilne w kolejnych modelach. Wartość parametru odpowiadającego wpływowi szerokości geograficznej, nieistotna statystycznie w modelu trendu powierzchniowego (por. tabela 2), wykazuje statystyczną istotność, przy czym wartość oszacowania waha się od 0,01 do 0,03 . Wartość parametru odzwierciedlającego zmiany wysokości płac - pod wpływem długości geograficznej - również nie jest stabilna i niższa od wartości oszacowanych $w$ oparciu o model trendu pomierzchniowego.

Mając na względzie wyniki oszacowań modeli trendu dla indeksu GCI (tabela 2), niestabilność oszacowań parametrów, za pomocą współliniowości zmiennych aproksymujących argumentować można położenie geograficzne i poziom konkurencyjności gospodarki. W celu wyeliminowania wpływu trendu przestrzennego indeksu GCI na oszacowanie pozostałych parametrów, estymacji poddano modele, w których wartość wskaźnika konkurencyjności zastąpiono resztami z estymacji modeli trendu powierzchniowego, które odpowiadały wartościom indeksu GCI skorygowanym o trend przestrzenny. Wyniki estymacji (tabela 3, model 2) potwierdzają zasadność korekty. W szczególności uzyskano stabilne oszacowanie parametrów odpowiadających wpływowi długości geograficznej, zaś ich wartość jest zgodna $\mathrm{z}$ wynikami w modelach trendu powierzchniowego. $\mathrm{Z}$ uwagi na brak istotności statystycznej, z modeli usunięto zmienną odpowiadającą szerokości geograficznej. Siła oddziaływania indeksu konkurencyjności na poziom płac nie uległa zmianie w porównaniu z modelem 1.

W dalszej kolejności - W celu weryfikacji postaci funkcyjnej trendu przestrzennego - estymacji poddano modele, w których przestrzenna tendencja rozwojowa wyrażona została wielomianem drugiego stopnia (tabela 4). W przypadku indeksu GCI uzyskane wyniki wskazują, iż wielomian drugiego stopnia lepiej wyjaśnia przestrzenne zmiany poziomu konkurencyjności. Współczynnik determinacji każdorazowo był wyższy niż w modelach trendu liniowego. Analogicznie, kwadrat długości geograficznej lepiej wyjaśnia zmiany poziomu płac godzinowych $\left(R^{2}=27 \%\right)$ niż długość geograficzna $\left(R^{2}=20 \%\right)$. Wizualizacje trendu przestrzennego w postaci wielomianu drugiego stopnia dla obu zmiennych zaprezentowano na rysunku 4. 
Tabela 4. Wyniki estymacji modeli trendu powierzchniowego w postaci wielomianu drugiego stopnia dla indeksu GCI i płac godzinowych

\begin{tabular}{|c|c|c|c|c|c|c|c|}
\hline \multirow[b]{2}{*}{$\begin{array}{l}\text { Zmienna } \\
\text { zależna }\end{array}$} & \multirow[b]{2}{*}{ Parametr } & \multicolumn{6}{|c|}{ Indeks GCl (2) } \\
\hline & & $\alpha$ & $\operatorname{se}(\alpha)$ & $\mathrm{R}_{\text {skor. }}{ }^{2}$ & $\begin{array}{l}\text { Test Shapiro- } \\
\text {-Wilka }\end{array}$ & $\begin{array}{l}\text { Test Breuscha- } \\
\text {-Pagana }\end{array}$ & $\begin{array}{c}\text { Test istotności } \\
\text { Morana I }\end{array}$ \\
\hline $\ln \left(\mathrm{GCl}_{2009}\right)$ & $\begin{array}{l}\text { const. } \\
\operatorname{coor} \mathrm{X}^{2} \\
\operatorname{coor} \mathrm{Y}^{2}\end{array}$ & $\begin{array}{c}1,40^{\star *} \\
-0,00^{\star *} \\
0,00^{\star *}\end{array}$ & $\begin{array}{l}0,05 \\
0,00 \\
0,00\end{array}$ & $42 \%$ & 0,62 & 0,09 & $0,00^{* *}$ \\
\hline $\ln \left(\mathrm{GCl}_{2008}\right)$ & $\begin{array}{l}\text { const. } \\
\text { coor } X^{2} \\
\text { coor } Y^{2}\end{array}$ & $\begin{array}{c}1,39^{* *} \\
-0,00^{* *} \\
0,00^{* *}\end{array}$ & $\begin{array}{l}0,05 \\
0,00 \\
0,00\end{array}$ & $49 \%$ & 0,30 & 0,07 & $0,00^{* *}$ \\
\hline $\ln \left(\mathrm{GCl}_{2007}\right)$ & $\begin{array}{l}\text { const. } \\
\text { coor } \mathrm{X}^{2} \\
\text { coor } \mathrm{Y}^{2}\end{array}$ & $\begin{array}{c}1,37^{\star *} \\
-0,00^{\star *} \\
0,00^{\star *}\end{array}$ & $\begin{array}{l}0,05 \\
0,00 \\
0,00\end{array}$ & $57 \%$ & 0,21 & 0,07 & $0,01^{* *}$ \\
\hline $\ln \left(\mathrm{GCl}_{2006}\right)$ & $\begin{array}{l}\text { const. } \\
\text { coor } X^{2} \\
\text { coor } Y^{2}\end{array}$ & $\begin{array}{c}1,38^{\star *} \\
-0,00^{\star *} \\
0,00^{\star *}\end{array}$ & $\begin{array}{l}0,05 \\
0,00 \\
0,00\end{array}$ & $61 \%$ & 0,90 & 0,05 & $0,01^{* *}$ \\
\hline \multirow[t]{2}{*}{$\ln \left(\mathrm{GCl}_{2005}\right)$} & $\begin{array}{l}\text { const. } \\
\text { coor } \mathrm{X}^{2} \\
\text { coor } \mathrm{Y}^{2} \\
\end{array}$ & $\begin{array}{l}1,32^{\star *} \\
-0,00^{*} \\
0,00^{\star *}\end{array}$ & $\begin{array}{l}0,07 \\
0,00 \\
0,00 \\
\end{array}$ & $43 \%$ & 0,99 & 0,18 & $0,04^{*}$ \\
\hline & & \multicolumn{6}{|c|}{ Płace godzinowe (2) } \\
\hline $\ln \left(\right.$ Wage $\left._{2010}\right)$ & $\begin{array}{l}\text { const. } \\
\text { coor } X^{2}\end{array}$ & $\begin{array}{c}2,65^{\star *} \\
-0,00^{\star *}\end{array}$ & $\begin{array}{l}0,00 \\
0,00 \\
\end{array}$ & $27 \%$ & 0,62 & $0,01^{*}$ & $0,00^{* *}$ \\
\hline
\end{tabular}

** $\mathrm{p}<0,01 ; * \mathrm{p}<0,05$. Dla testu Shapiro-Wilka, Breuscha-Pagana i testu istotności globalnej autokorelacji przestrzennej Morana $I$ podano wartość $p$-value. Wskaźnik Morana $I$ oszacowany dla macierzy dwóch najbliższych sąsiadów.

Źródło: obliczenia własne.
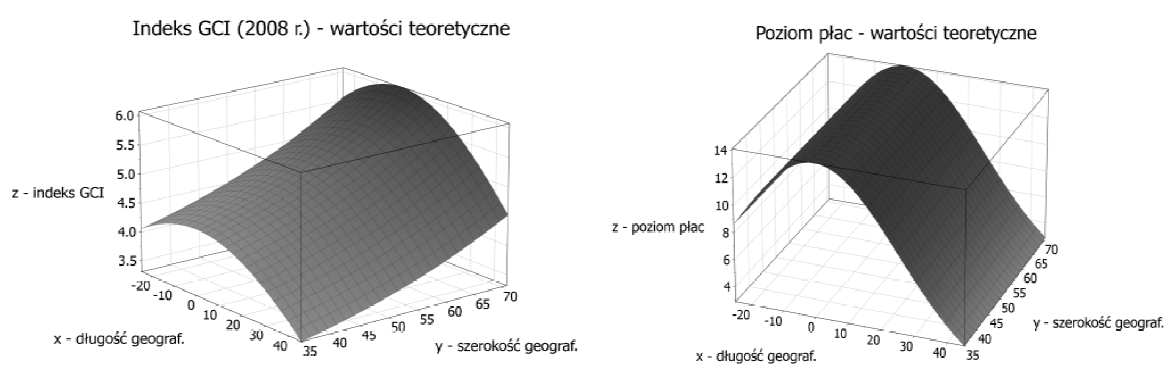

Rysunek 4. Trend powierzchniowy w postaci wielomianu drugiego stopnia indeksu GCI i wynagrodzeń

Źródło: opracowanie własne na podstawie tabeli 3.

Mimo iż trend przestrzenny wyrażony wielomianem drugiego stopnia lepiej odzwierciedla zmiany poziomu płac i indeksu konkurencyjności, wyniki estymacji modelu trendu powierzchniowego uwzględniającego wpływ 
konkurencyjności są porównywalne do uzyskanych przy wykorzystaniu trendu liniowego. W szczególności zauważyć można, że wartości współczynnika determinacji estymowanych modeli (tabela 5) są nieznacznie niższe niż w poprzednim przypadku (tabela 3). Oszacowanie parametru odpowiadającemu kwadratowi długości geograficznej jest zbliżone uzyskanych w modelach pozbawionych dodatkowej zmiennej objaśniającej w postaci indeksu GCI. Uzyskane wyniki wskazują, że do południka $0^{\circ}$ wzrost długości geograficznej powoduje wzrost poziomu płac, podczas gdy na półkuli wschodniej kolejne przyrosty długości geograficznej wiążą się z redukcją wysokości wynagrodzeń. Analogiczny kierunek zmian dostrzec można, posiłkując się rysunkiem 1.

Tabela 5. Wyniki estymacji modelu trendu powierzchniowego w postaci wielomianu drugiego stopnia z zależnością między płacami a konkurencyjnością gospodarki

\begin{tabular}{|c|c|c|c|c|c|c|}
\hline Parametr & $\alpha$ & $\operatorname{se}(\alpha)$ & $\mathrm{R}_{\text {skor. }}{ }^{2}$ & $\begin{array}{c}\text { Test Shapiro- } \\
\text {-Wilka }\end{array}$ & $\begin{array}{c}\text { Test Breuscha- } \\
\text {-Pagana }\end{array}$ & $\begin{array}{c}\text { Test istotności } \\
\text { Morana I }\end{array}$ \\
\hline const. & $2,65^{\star *}$ & 0,07 & & & & \\
\hline $\ln (\hat{G} C / 2009)$ & $3,46^{* *}$ & 0,56 & $67 \%$ & 0,91 & 0,30 & 0,09 \\
\hline $\operatorname{coor} X^{2}$ & $-0,00^{* *}$ & 0,00 & & & & \\
\hline const. & $2.65^{\star \star}$ & 0,07 & & & & \\
\hline $\ln \left(\hat{G} C l_{2008}\right)$ & $3,60^{\star *}$ & 0,58 & $67 \%$ & 0,83 & 0,30 & 0,15 \\
\hline $\operatorname{coor} X^{2}$ & $-0,00^{* *}$ & 0,00 & & & & \\
\hline const. & $2,65^{\star \star}$ & 0,07 & & & & \\
\hline $\ln \left(\hat{G} C l_{2007}\right)$ & $3,52^{\star *}$ & 0,65 & $63 \%$ & 0,33 & 0,38 & 0,13 \\
\hline coor $X^{2}$ & $-0,00^{* *}$ & 0,00 & & & & \\
\hline const. & $2,65^{\star \star}$ & 0,07 & & & & \\
\hline $\ln (\hat{G} C / 2006)$ & $3,79^{\star *}$ & 0,60 & $68 \%$ & 0,34 & 0,10 & 0,21 \\
\hline $\operatorname{coor} \mathrm{X}^{2}$ & $-0,00^{* *}$ & 0,00 & & & & \\
\hline const. & $2,65^{\star *}$ & 0,08 & & & & \\
\hline $\ln \left(\hat{G} C_{2005}\right)$ & $2,28^{* *}$ & 0,49 & $57 \%$ & 0,86 & 0,15 & $0,03^{*}$ \\
\hline $\operatorname{coor} \mathrm{X}^{2}$ & $-0,00^{* *}$ & 0,00 & & & & \\
\hline
\end{tabular}

** $\mathrm{p}<0,01 ; * \mathrm{p}<0,05$. Dla testu Shapiro-Wilka, Breuscha-Pagana i testu istotności globalnej autokorelacji przestrzennej Morana I podano wartość $p$-value. Wskaźnik Morana I oszacowany dla macierzy dwóch najbliższych sąsiadów.

Źródło: obliczenia własne.

Zasadnicza różnica między liniową funkcją trendu przestrzennego a funkcją $\mathrm{w}$ postaci wielomianu wiąże się $\mathrm{z}$ uwzględnieniem zróżnicowania poziomu płac godzinowych w krajach zlokalizowanych na półkuli zachodniej. W przypadku trendu liniowego nachylenie płaszczyzny w kierunku wschodnim pozwala wnioskować o systematycznej redukcji wynagrodzeń w miarę wzrostu długości geograficznej, jednak prawidłowość ta nie od- 
zwierciedla pozycji takich krajów jak: Islandia, Portugalia, Hiszpania, które powinny cechować się wyższym poziomem płac niż ich wschodni sąsiedzi, tj. Francja czy Wielka Brytania. Aproksymacja funkcji trendu przestrzennego wielomianem drugiego stopnia pozwala na uwzględnienie tego, że dla tych krajów mamy do czynienia z odwrotną zależnością. Niższe niż w przypadku trendu liniowego dopasowanie danych empirycznych do rzeczywistych świadczyć może, że dominujące znaczenie mają jednak różnice w poziomie wynagrodzeń między krajami Europy Wschodniej i Zachodniej, zaś zróżnicowanie w obrębie krajów Europy Zachodniej ma znaczenie drugorzędne, w szczególności w sytuacji możliwości wyjaśnienia wspomnianych zmian różnicami w konkurencyjności gospodarek.

\subsection{WNIOSKI}

Rezultaty analiz empirycznych wskazują na wpływ konkurencyjności na poziom przeciętnych godzinowych płac w krajach Europy. Siła oddziaływania indeksu GCI na wysokość wynagrodzeń maleje z kolejnymi opóźnieniami wskaźnika konkurencyjności w przypadku modeli regresji liniowej, zaś w modelach trendu powierzchniowego utrzymuje się na zbliżonym poziomie i ulega znaczącej redukcji dopiero dla opóźnienia rzędu $t-5$ (rysunek 5). Zależność ta dotyczy wyłącznie oddziaływania na poziom płac w 2010 r.

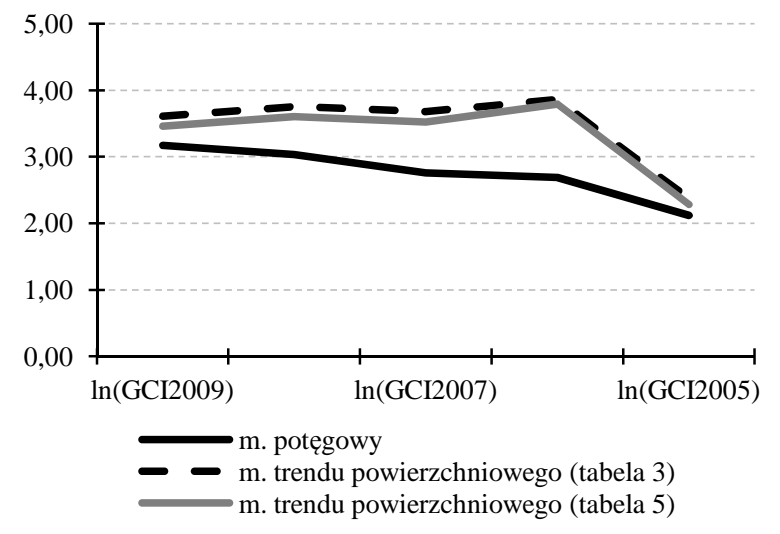

Rysunek 5. Wartości oszacowań parametru $\beta$ odzwierciedlającego wpływ konkurencyjności na poziom płac godzinowych - porównanie wyników

Źródło: opracowanie własne na podstawie tab. 3 i 4.

Warto zauważyć, że oszacowania parametru $\beta$ nie są podatne na zmiany postaci funkcyjnej przestrzennej tendencji rozwojowej, zaś korekta zmiennej aproksymującej konkurencyjność nie wpłynęła na zmiany wartości oszaco- 
wań parametru. W przypadku tej samej wartości indeksu GCI we wszystkich krajach, te zlokalizowane w Europie Zachodniej będą cechować się jednak wyższym poziomem wynagrodzeń godzinowych w porównaniu z krajami Europy Wschodniej. Tym samym stwierdzić można, że wyjaśnienie przyczyn zróżnicowania poziomu płac godzinowych pozycją konkurencyjną gospodarki jest niewystarczające. W szczególności rozważana zmienna nie jest w stanie wyjaśnić systematycznej niejednorodności przestrzennej wysokości wynagrodzeń, którą odzwierciedla funkcja trendu powierzchniowego.

\section{PODSUMOWANIE}

Celem pracy była weryfikacja hipotez dotyczących wpływu konkurencyjności na poziom płac w krajach Europy oraz istnienia przestrzennej tendencji rozwojowej wysokości wynagrodzeń (w 2010 r.). Uzyskane wyniki potwierdzają pozytywny wpływ konkurencyjności na wysokość płac na szczeblu krajowym, przy czym oddziaływanie to odznacza się opóźnieniem czasowym. Dodatkowo wykazano zasadność uwzględnienia przestrzennej tendencji rozwojowej zjawiska, uzyskując istotne statystycznie różnice w poziomie zmiennej w zależności od długości geograficznej. W szerszym kontekście rezultaty badań potwierdzają zasadność analizy trendu przestrzennego w przypadku zmiennych odzwierciedlających sytuację na rynku pracy.

\section{LITERATURA}

Chojnicki Z., Czyż T. (1975), Zastosowanie analizy trendu powierzchniowego $w$ geografii, „Przegląd Geograficzny”, 47(2), PWN, Warszawa.

Jagiełło M. (2008), Strategiczne budowanie konkurencyjności gospodarki, Wydawnictwo Poltex, Warszawa.

Kłosiński K. (2004), Rozwój konkurencyjności gospodarek, [w:] Kłosiński K. (red.), Konkurencyjność oraz rozwój w gospodarce, Wydawnictwo KUL, Lublin.

Kwiatkowski E., Kucharski L. (2011), Konkurencyjność gospodarki a poziom wynagrodzeń (analiza na przyktadzie polskich powiatów), Zeszyty Naukowe PTE, 9, 145-158.

Lewandowska-Gwarda K. (2013), Rola przestrzeni w badaniach ekonomicznych, „Acta Universitatis Nicolai Copernici, Ekonomia", 44, 145-158,

DOI: http://dx.doi.org/10.12775/AUNC_ECON.2013.011.

Liu F. (2010), Environmental Justice Analysis. Theories, Methods, and Practice, CRC Press, Florida.

Pietrzak M. B. (2010), Problem identyfikacji struktury danych przestrzennych, „Acta Universitatis Nicolai Copernici, Ekonomia”, 41, 83-98.

Schwab K., Sala-i-Martin X., Greenhill R. (2009), The Global Competitiveness Report 2009-2010 , World Economic Forum, Genewa.

Suchecki B. (red.) (2010), Ekonometria przestrzenna. Metody i modele analizy danych przestrzennych, Wydawnictwo C.H. Beck, Warszawa. 


\section{THE INFLUENCE OF COMPETITIVENESS ON WAGES IN THE EUROPEAN COUNTRIES. APPLICATION OF THE TREND SURFACE ANALYSIS}

A b s tract. The aim of this article is the analysis of the impact of the competitiveness on the average hourly wages in selected European countries. Additionally, the attempt to identify the spatial trend of the wage is made. The trend surface model, based on the country capitals' coordinates is used. The conclusions from this work may highlight the value of the spatial aspects inclusion in the economic research.

K e y w o r d s: competitiveness, wages, trend surface analysis. 